\title{
The Relationship between Global Solar Radiation and Sunshine Durations in Cameroon
}

\author{
R. Mbiaké1, A. Beya Wakata², E. Mfoumou'3 , E. Ndjeuna4, L. Fotso', E. Tiekwe1, \\ J. R. Kaze Djamen ${ }^{5}$, C. Bobda 6 \\ ${ }^{1}$ University of Douala, Faculty of Sciences, Douala, Cameroon \\ ${ }^{2}$ University of Yaoundé, Faculty of Sciences, Yaoundé, Cameroon \\ ${ }^{3}$ Nova Scotia Community College, Division of Applied Research, Springhill, Canada \\ ${ }^{4}$ Ecole Normale Supérieure d'Enseignement Technique (ENSET), Douala, Cameroon \\ ${ }^{5}$ Centre de Physique Atomique, Moléculaire Optique et Quantique (CEPAMOQ), Douala, Cameroon \\ ${ }^{6}$ Public Health of the San Diego University, San Diego, USA \\ Email: rmbiake@yahoo.fr, rmbiake85@gmail.com
}

How to cite this paper: Mbiaké, R., Beya Wakata, A., Mfoumou, E., Ndjeuna, E., Fotso, L., Tiekwe, E., Kaze Djamen, J.R. and Bobda, C. (2018) The Relationship between Global Solar Radiation and Sunshine Durations in Cameroon. Open Journal of Air Pollution, 7, 107-119.

https://doi.org/10.4236/ojap.2018.72006

Received: January 10, 2018

Accepted: June 11, 2018

Published: June 14, 2018

Copyright $\odot 2018$ by authors and Scientific Research Publishing Inc. This work is licensed under the Creative Commons Attribution International License (CC BY 4.0).

http://creativecommons.org/licenses/by/4.0/

\section{c) (i) Open Access}

\begin{abstract}
Based on the well-known modified Angstrom formula on the relationship between the sunshine duration and the global solar radiation, this paper aimed to estimate the value of the constant $a$ and $b$ in Cameroon. Only five cities (Maroua, Garoua, NGaoundéré, Yaoundé and Douala) had the both available in-situ data recorded during the period of eleven years (1996-2006) beside which four others cities (Dschang, Koundja, Yoko and Manfé) had only the in-situ sunshine duration available data recorded during the period of twenty years (1986-2006). The 9 cities were grouped in 3 different climate regions. Based on the data of the 5 first cities belonging the 3 regions, the follow constant values $a_{1}=-0.05, a_{2}=-0.02, a_{3}=-0.14$ and $b_{1}=0.94, b_{2}=0.74, b_{3}=$ 1.12 were obtained. The Root Mean Square Error (RMSE) Mean Bias Error (MBE) and correlation coefficient $(r)$ were also determined. Then we used these values to estimate the global solar radiation for the other four remain cities. The constants $a$ and $b$ obtained values are in accordance with those of the West Africa region which Cameroon belongs to. So they can be employed in estimating global solar radiation of location in Cameroon paying attention only to the geographical location information.
\end{abstract}

\section{Keywords}

Solar Radiation, Sunshine Duration, Angstrom Constants, Climatic Region

\section{Introduction}

Energy is the motive force behind the sustained technology development, especially for developing countries, where the renewable energy is capable of sup- 
plying the necessary energy for their rapid development. The awareness of the limited availability of non-renewable resources and their associated environmental problems is making it imperative that the world shift emphasizes the renewable energy resources. The environment consequences of harnessing these non-renewable energy sources are assuming alarming proportions.

So, the knowledge of global solar radiation and the sunshine duration received during the average day of each month are prerequisite in any solar energy exploitation for the optimal design and the prediction of the system performance. Obviously the best way of knowing the amount of global solar radiation at a given site is to install Pyrhéliomètre as possible at many locations in the region and look after them day to day.

A global study of the world distribution of the solar radiation has been carried out by Lof et al. [1] and Gueymard et al. [2], while there have been many attempts to find common models applicable anywhere in the world [3]. Beside these studies, the Angstrom-Prescott relationship has been examined in many countries throughout the world, e.g. Australia [4], Canada [5], Caribbean countries as Guatemala [6], the West Indies [7], South Asian countries such as Sri Lanka [8], Pakistan [9] in Africa continent Nigeria [10], Sudan [11], and South East Asia as Hong Kong [12].

Nevertheless, one can notice that comparing to Northern countries, where there is a several hundreds of ground meteorological stations directly and indirectly measuring solar radiation, and continuous irradiance values deriving directly from the meteorological geostationary satellites (e.g.; METEOSAT), the countries in development face with the insufficient of these meteorology stations. Definitively in these regions, modeling is the better tool for estimating incoming global solar radiation from the sunshine duration, in a day of location where the measurements are not available [13].

To reduce this gap in the African continent, this work aims to improve the global solar radiation in Cameroon by it estimation for the four cities (Manfé, Koundja, Yoko and Dschang) where only daily sunshine records are available.

\section{Methodology}

\subsection{Theoretical Aspect}

Theoretically, the global solar radiation that reaches at the earth's surface is a result of complex interactions between the solar radiations at the top of the earth's atmosphere evaluated by the solar constant $G_{s c}=1369 \pm 6 \mathrm{~W} / \mathrm{m}^{2}$ and the climatic conditions of the location. This evaluation does take also into account the rotation of the earth about its own axis and by its elliptical orbit about the sun and the solar declination (o). Excluding the meteorological and climatic conditions, the daily extraterrestrial solar radiation $H_{0}$ on a horizontal surface for a day in a month is well approximated by the given expression [14]:

$$
H_{0}=G_{s c} \times\left(\frac{R_{0}}{R}\right)^{2} \times \frac{24 \times 3600}{\pi} \times[\cos (L) \cos (\delta) \cos (\omega)+\sin (L) \sin (\delta)]
$$


$L$ is the latitude and $\omega$ is the solar hour angle. The solar declination $(\delta)$ is expressed by:

$$
\delta=23.45 \sin [0.986 \times(J+284)]
$$

Equation (1) overestimates the global irradiation as it does not take into account the interaction with atmosphere's components. Indeed, the intensity of solar radiation through the atmosphere is attenuated by various atmospheric constituents, namely gases (air, molecules, ozone, $\mathrm{CO}_{2}, \mathrm{OH}$, etc.), liquid and solid particles (aerosols $\mathrm{PM}_{2.5}, \mathrm{PM}_{10}$ and clouds). This attenuation is mainly due to clouds, and the path length through atmosphere is also critical.

Facing with the insufficiency and the quality of the in-situ measurement global solar radiation data, and the overestimation of the global irradiation by Equation (1), let us used in this paper the general empirical approach formula pioneered by angstrom in 1942 [15], and later completed by Prescott 1940 [16]. This formula relates average daily global radiation with average daily sunshine hours:

$$
\bar{H}=\bar{H}_{0}\left(a+b \frac{\bar{d}}{\bar{d}_{0}}\right)
$$

where $a, b$ are the constants to be determined. $\bar{d}$ is the monthly mean daily bright sunshine duration obtained by the Campbell-Stokes recorder, and $\bar{d}_{0}$ is the highest monthly mean daily sunshine duration that can be calculated using the followed expression:

$$
\bar{d}_{0}=\frac{2}{15} \cos ^{-1}(\tan \delta \times \tan L)
$$

\subsection{Solar Radiation Data in Cameroon}

Despite the lowest availability of the radiation in-situ instruments at meteorological stations in Cameroon, we used in this paper, the sunshine duration of nine (9) stations and five (5) global solar radiations of them. These data were furnished by the Cameroon National Meteorological Office (DNM).

Based on the Trewarth's climatic classification [17], the 9 stations were grouped by region. Owing to its geographical position stretching from latitude $4^{\circ} \mathrm{N}$ to $14^{\circ} \mathrm{N}$, Cameroon belongs to three following types of climate. Douala, Yaoundé, Manfé and Dschang cities belonging to latitude $3^{\circ} 50^{\prime} \mathrm{N}$ and $5^{\circ} 45^{\prime} \mathrm{N}$ make up the first region with a humid subtropical climate. The second region stretching from latitude $5^{\circ} 50^{\prime} \mathrm{N}$ to $7^{\circ} 30^{\prime} \mathrm{N}$ with a tropical wet climates contains the cities of Yoko, Koundja and N'Gaoundéré, while a warm and dry climate make up the third region with Garoua and Maroua. The 9 stations shared out in the 3 regions are presented in Table 1.

Among the 9 meteorological stations where these data were recorded, only 5 had the both types of data: the hour's solar length in a day (d) and the global solar radiation $(H)$ (Table 2 ). 
Table 1. Geographical location of cities and records length.

\begin{tabular}{|c|c|c|c|c|c|}
\hline & & Location & & & \\
\hline Location & Latitude & Longitude & Height (m) & $\begin{array}{c}\text { Solar } \\
\text { radiation }\end{array}$ & Sunshine duration \\
\hline \multicolumn{6}{|c|}{ Region 1} \\
\hline Yaoundé & $03^{\circ} 50^{\prime} \mathrm{N}$ & $11^{\circ} 31^{\prime} \mathrm{E}$ & 760 & 1996-2005 & $1986-2006$ \\
\hline Douala & $04^{\circ} 01^{\prime} \mathrm{N}$ & $09^{\circ} 44^{\prime} \mathrm{E}$ & 005 & 1996-2006 & $1986-2006$ \\
\hline Manfé & $05^{\circ} 40^{\prime} \mathrm{N}$ & $09^{\circ} 20^{\prime} \mathrm{E}$ & 126 & - & 1980-1996 \\
\hline Dschang & $05^{\circ} 45^{\prime} \mathrm{N}$ & $10^{\circ} 04^{\prime} \mathrm{E}$ & 1399 & - & 1981-1999 \\
\hline \multicolumn{6}{|c|}{ Region 2} \\
\hline Yoko & $05^{\circ} 54^{\prime} \mathrm{N}$ & $12^{\circ} 20^{\prime} \mathrm{E}$ & 1031 & - & 1981-1996 \\
\hline Koundja & $05^{\circ} 63^{\prime} \mathrm{N}$ & $10^{\circ} 50^{\prime} \mathrm{E}$ & 1217 & - & 1981-1999 \\
\hline N'Gaoundéré & $07^{\circ} 21^{\prime} \mathrm{N}$ & $13^{\circ} 33^{\prime} \mathrm{E}$ & 933 & 1996-2006 & $1976-2006$ \\
\hline \multicolumn{6}{|c|}{ Region 3} \\
\hline Garoua & $09^{\circ} 20^{\prime} \mathrm{N}$ & $13^{\circ} 23^{\prime} \mathrm{E}$ & 242 & 1996-2006 & 1986-2006 \\
\hline Maroua & $10^{\circ} 27^{\prime} \mathrm{N}$ & $14^{\circ} 15^{\prime} \mathrm{E}$ & 394 & $1996-2004$ & $1986-2006$ \\
\hline
\end{tabular}

Table 2. Stations with global solar radiation and sunshine duration availables.

\begin{tabular}{|c|c|c|c|c|c|}
\hline \multicolumn{6}{|c|}{ Location } \\
\hline Location & Latitude & Longitude & Height (m) & $\begin{array}{c}\text { Solar } \\
\text { Radiation }\end{array}$ & $\begin{array}{l}\text { Sunshine } \\
\text { Duration }\end{array}$ \\
\hline \multicolumn{6}{|c|}{ Region 1} \\
\hline Yaoundé & $03^{\circ} 50^{\prime} \mathrm{N}$ & $11^{\circ} 31^{\prime} \mathrm{E}$ & 760 & 1996-2005 & $1986-2006$ \\
\hline Douala & $04^{\circ} 01^{\prime} \mathrm{N}$ & $09^{\circ} 44^{\prime} \mathrm{E}$ & 005 & $1996-2006$ & 1986-2006 \\
\hline \multicolumn{6}{|c|}{ Region 2} \\
\hline N'Gaoundéré & $07^{\circ} 21^{\prime} \mathrm{N}$ & $13^{\circ} 33^{\prime} \mathrm{E}$ & 933 & $1996-2006$ & 1986-2006 \\
\hline \multicolumn{6}{|c|}{ Region 3} \\
\hline Garoua & $09^{\circ} 20^{\prime} \mathrm{N}$ & $13^{\circ} 23^{\prime} \mathrm{E}$ & 242 & $1996-2006$ & 1986-2006 \\
\hline Maroua & $10^{\circ} 27^{\prime} \mathrm{N}$ & $14^{\circ} 15^{\prime} \mathrm{E}$ & 394 & $1996-2004$ & 1986-2006 \\
\hline
\end{tabular}

For the 9 stations, the monthly average daily values over 10 to 20 years of measured data for the sunshine length hours were computed. Figure 1(a); Figure 2(a); Figure 3(a) are the curve of the measured values of the monthly average daily sunshine duration of the 3 climatic regions. And Figure 1(b), Figure 2(b), and Figure 3(b) are the mean value for each of them.

All the obtained plots brought out the similar trend of the monthly average daily sunshine. However, when we draw the 3 region curves on the same graph (Figure 4), it appears curiously that they have the same horizontal trend while their vertical positions is related to the latitudinal coordinate and the type of climate from the wet to the dry one.

Taking into account the above climatic classification, the only 5 stations that had in-situ recorded global solar radiation were grouped by region according to Table 2.

After the sunshine duration, we draw as one can see on Figure 5 the trend of the monthly average daily global solar radiation for the 5 stations that have these data. Once again, the 5 form curves have the same annual trend, while the graph 


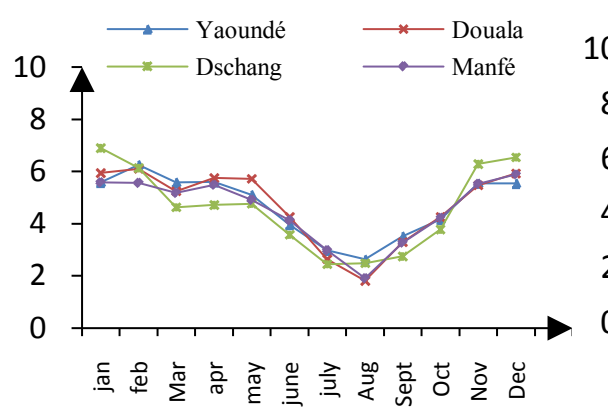

(a)

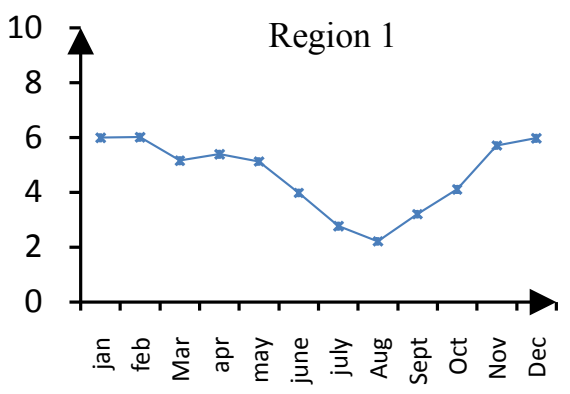

(b)

Figure 1. (a) Monthly average daily sunshine duration for the 4 stations of region 1; (b) Mean value of the monthly average daily sunshine duration for region 1 .

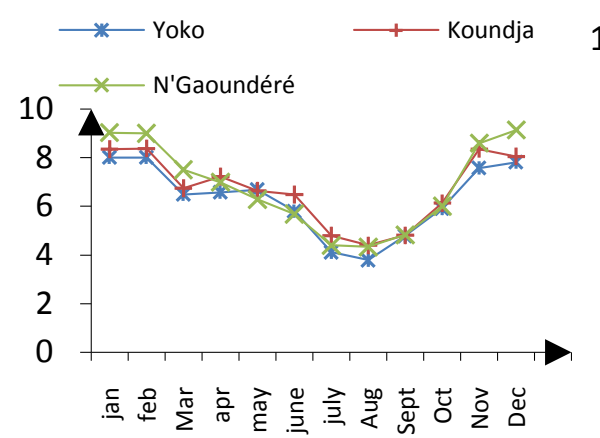

(a)

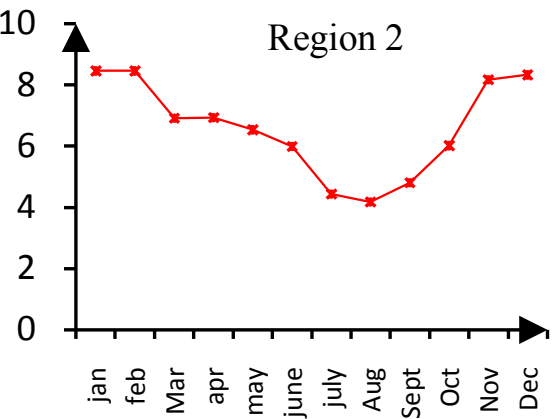

(b)

Figure 2. (a) Monthly average daily sunshine duration for the 3 stations of region 2; (b) Mean value of the monthly average daily sunshine duration for region 2 .

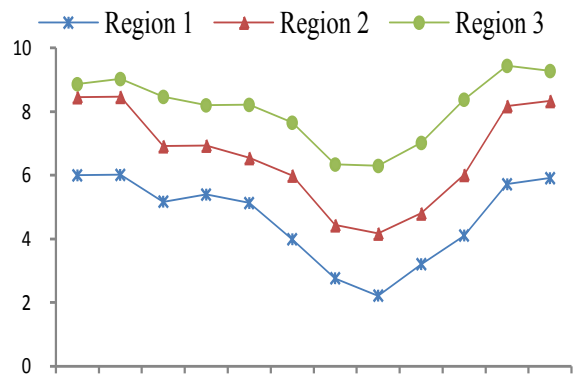

jan feb Mar apr may june july Aug Sept Oct Nov Dec

(a)

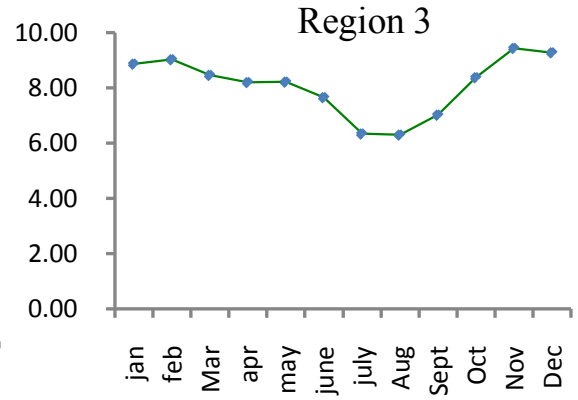

(b)

Figure 3. (a) Monthly average daily sunshine duration for the 2 stations of region 3; (b) Mean value of the monthly average daily sunshine duration for region 3 .

position depends to the region. Based on these curves trend and the way they gathered together in Figure 5, we draw in Figure 6 the blue curve to express the dry climate global solar radiation $H_{d}$ and in red the humid subtropical one $H_{h}$.

\subsection{Local Values of Angstrom-Prescott Constants}

To estimate the unknown global solar radiation values of the 4 other stations, we computed the regression coefficients $a$ and $b$ using the following equations: 


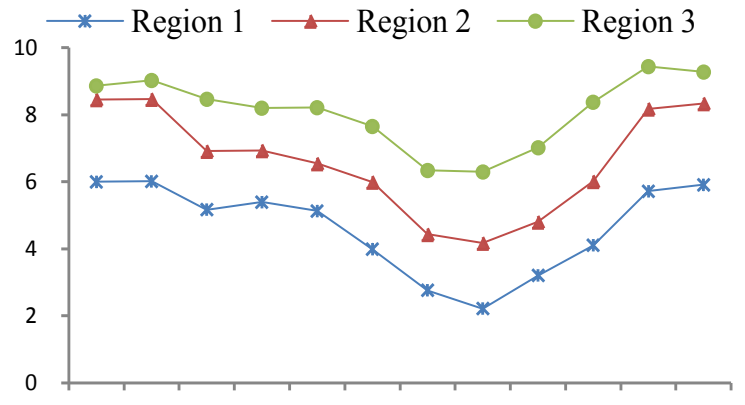

jan feb Mar apr may june july Aug Sept Oct Nov Dec

Figure 4. Monthly average daily sunshine.

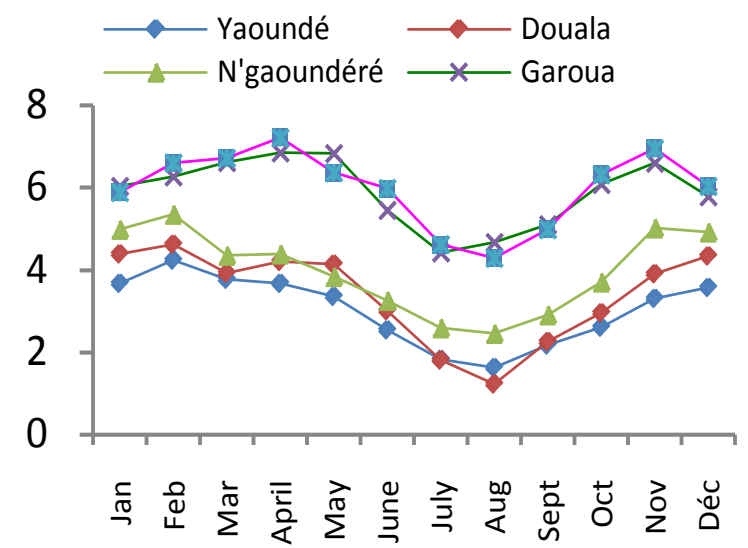

Figure 5. Monthly average daily global solar radiation for the 5 stations.

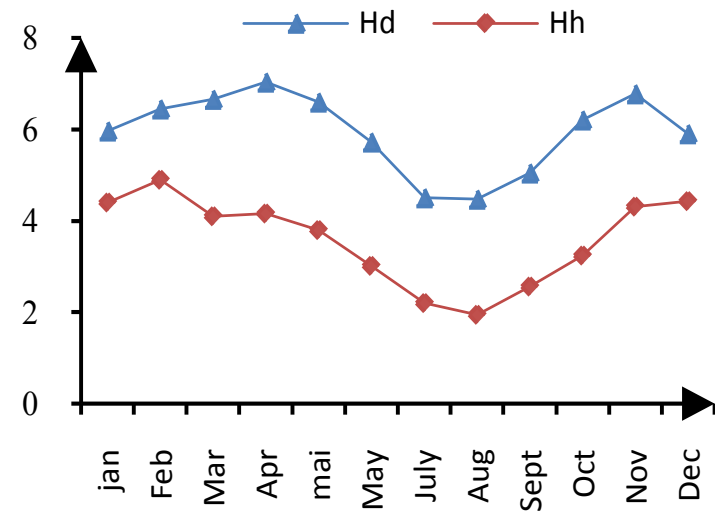

Figure 6. Monthly average daily global solar radiation for dry and humid climate.

$$
a=\frac{\left[\left(\sum \frac{\bar{H}}{\bar{H}_{0}}\right)\left(\sum\left(\frac{\bar{d}}{\bar{d}_{0}}\right)^{2}\right)\right]-\left[\left(\sum \frac{\bar{d}}{\bar{d}_{0}}\right)\left(\sum\left(\frac{\bar{d}}{\bar{d}_{0}}\right)\left(\frac{\bar{H}}{\bar{H}_{0}}\right)\right)\right]}{\left[M \sum\left(\frac{\bar{d}}{\bar{d}_{0}}\right)^{2}-\left(\sum \frac{\bar{d}}{\bar{d}_{0}}\right)^{2}\right]}
$$




$$
b=\frac{M\left(\sum\left(\frac{\bar{d}}{\bar{d}_{0}}\right)\left(\frac{\bar{H}}{\bar{H}_{0}}\right)\right)-\left[\left(\sum \frac{\bar{d}}{\bar{d}_{0}}\right) \sum\left(\frac{\bar{H}}{\bar{H}_{0}}\right)\right]}{\left[M \sum\left(\frac{\bar{d}}{\bar{d}_{0}}\right)^{2}-\left(\sum \frac{\bar{d}}{\bar{d}_{0}}\right)^{2}\right]}
$$

The obtained values were then used in Equation (3) to estimate the values of the global solar radiation $\bar{H}_{\text {est }}$ which were compared to its corresponding measured values $\bar{H}_{\text {mes }}$ at each of the 5 stations of Table 2 . The deviation between the estimated and the measured values were summarized by calculating the following statistical parameters: Mean Bias Error (MBE), Root Mean Square Error (RMSE) and correlation coefficient $r$.

$$
\operatorname{MBE}(\%)=100\left(\frac{1}{\bar{H}_{M}}\right)\left(\sum_{i} \frac{E_{i}}{M}\right) \quad \operatorname{RMSE}(\%)=100\left(\frac{1}{\bar{H}_{M}}\right) \sqrt{\left(\sum_{i} \frac{E_{i}^{2}}{M}\right)}
$$

where $E_{i}=\bar{H}_{\text {est }}-\bar{H}_{\text {mes }}$ with $i=1, M$ was the total number of the observations points.

$$
r=\frac{\sum\left(\bar{H}_{e s t}-\bar{H}_{E}\right)\left(\bar{H}_{m e s}-\bar{H}_{M}\right)}{\sqrt{\left(\sum\left(\bar{H}_{e s t}-\bar{H}_{E}\right)^{2} \sum\left(\bar{H}_{m e s}-\bar{H}_{M}\right)^{2}\right)}}
$$

Angstrom constants and statistical parameters are compiled in Table 3.

Noticing that the both solar parameters were almost the same at a close latitudinal coordinate we determined the mean values of each region (Table 4).

To validate our model, we tested it by using Rietveld and Turton models [3] [18] that could be considered most likely to be appropriate.

Let's recall that the Turton's model analyzes on a long term monthly average sunshine duration and global solar radiation data from 25 stations especially in humid tropical countries around the world in the both hemispheres. The formulation of his model is:

$$
\frac{\bar{H}}{\bar{H}_{0}}=0.30+0.40\left(\frac{\bar{d}}{\bar{d}_{0}}\right)
$$

Table 3. The results of the angstrom and Prescott model applied for Cameroon.

\begin{tabular}{cccccc}
\hline Location & $\mathbf{a}$ & $\mathbf{b}$ & MBE (\%) & RMSE (\%) & $\mathbf{r}$ \\
\hline & & \multicolumn{5}{c}{ Region 1 } \\
\hline Yaoundé & -0.05 & 0.90 & 0.36 & 3.46 & 0.94 \\
Douala & -0.04 & 0.98 & -0.15 & 4.46 & 0.95 \\
\hline & & & Region 2 & \\
\hline N'Gaoundéré & -0.02 & 0.74 & 0.022 & 0.95 \\
\hline Garoua & -0.13 & 1.10 & 0.03 & \\
Maroua & -0.15 & 1.13 & -0.37 & & \\
\hline
\end{tabular}


Table 4. The results of the Angstrom and Prescott model applied for Cameroon.

\begin{tabular}{cccccc}
\hline Location & $\mathrm{a}$ & $\mathrm{b}$ & MBE (\%) & RMSE (\%) & r \\
\hline Region 1 & -0.05 & 0.94 & -3.27 & 4.71 & 0.98 \\
Region 2 & -0.02 & 0.74 & 0.22 & 2.77 & 0.95 \\
Region 3 & -0.14 & 1.12 & 0.56 & 5.56 & 0.96 \\
\hline
\end{tabular}

While Rietveld's model applied to 42 stations in different countries around the world that were selected to collect the same data, expecting to derive a unified correlation applicable anywhere in the world. The follow relation was established:

$$
\frac{\bar{H}}{\bar{H}_{0}}=0.18+0.62\left(\frac{\bar{d}}{\bar{d}_{0}}\right)
$$

Based on this two Equations (9) and (10) for the test, we used the length day $\bar{d}_{0}$ and the sunshine duration averages $\bar{d}$ to estimate the value of the global solar radiation for the 3 regions.

Afterwards we compared the outcome estimated values of global solar radiation with the local values of the regions (Table 5).

Table 7 contains the must values of $a, b$ constants calculated around the world. These values let the constants of the region 1 to be the best to estimate the global solar radiation of the four remain cities namely Manfé, Koundja, Yoko and Dschang.

\subsection{Estimation of the Unknown Solar Radiation}

Amongst all these $a, b$ constants in Table 7, it stand out that the best one to estimate the unknown global solar radiations of the Manfé, Koundja, Yoko and Dschang cities are those of the region 1 of our country model with the closeness of their geographical coordinates.

The outcome computed values are compiled in Table 8 and Figure 7. We have the graph of the estimated global unknown global solar radiation and the figure shows once again the trend coherence of the vertical position that it is linked to the geographic position.

\section{Results and Discussion}

Despite the fact that Driesse and Thervenard [19] pointed out the error prone in the measurement of the sunshine duration due for instance, the threshold that depends on the humidity of the recording card Iqbal [20], or the human factors in the evaluation of the track burned by the Campbell-Stoke device introduces variability in sunshine recordings Baumgartner [21], Painter [22]. The both limits can lead to the over or under estimation the sunshine duration at different times.

To go around this variability of expressing the sunshine duration in term of the average daily beam radiation $H_{b}$, the model suggested by Suehrcke (2000) [23]: 
Table 5. Comparison between the 3 models: country, Turton's and Rietveld's models, based on the measured and estimated solar radiations.

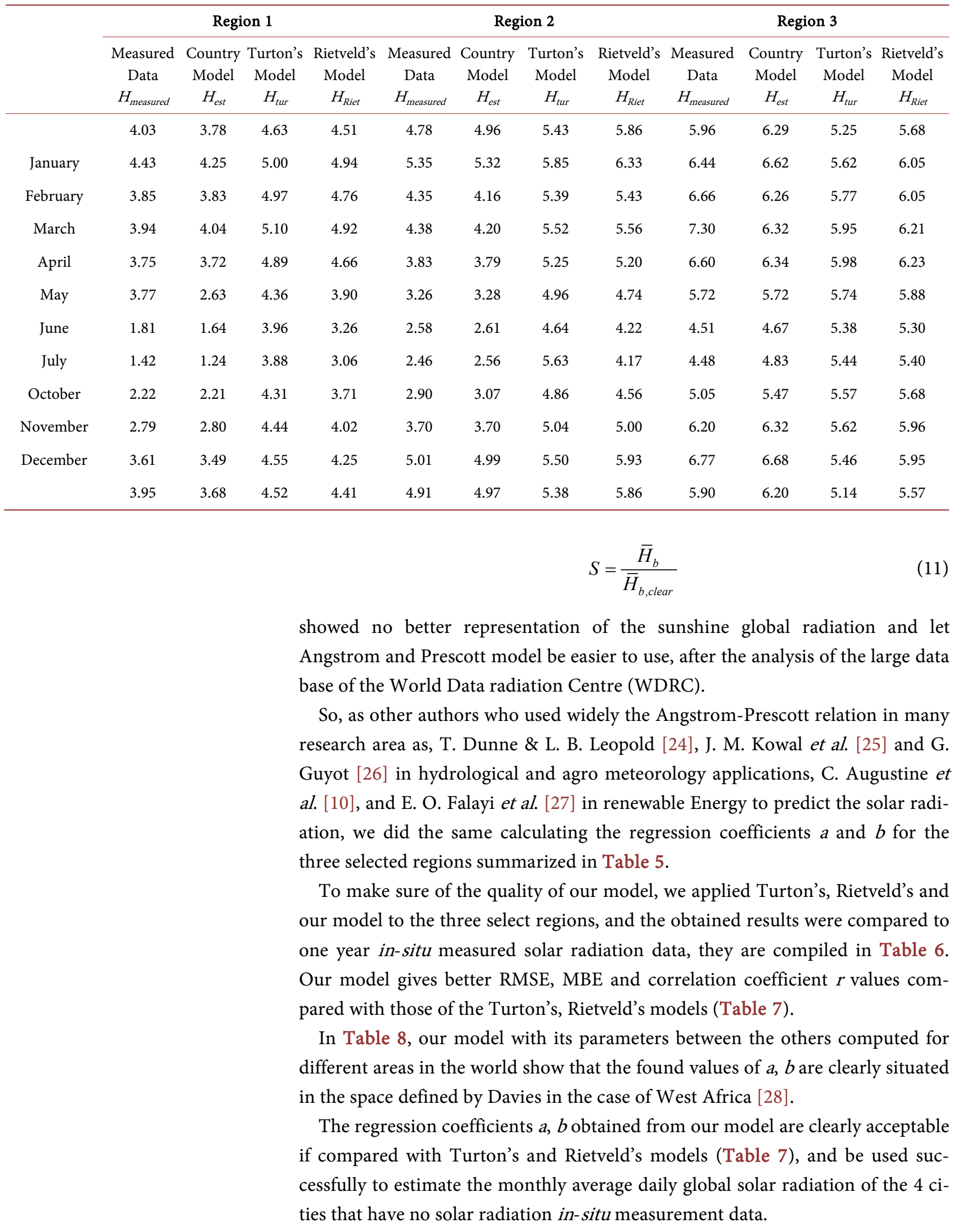



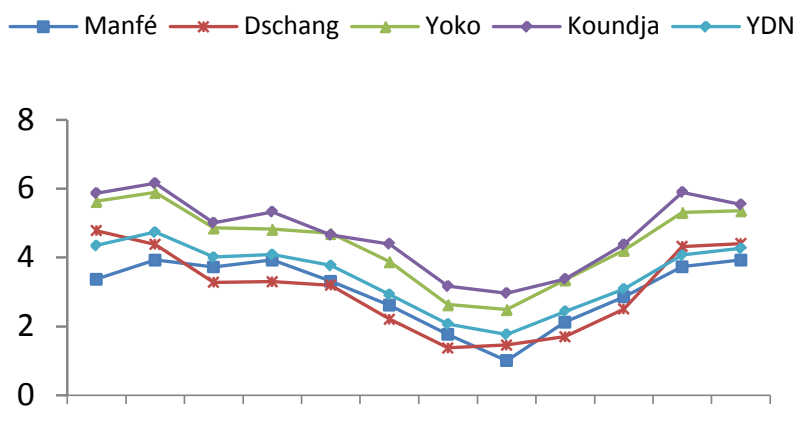

Jan Feb Mar April May June July Aug Sept Oct Nov Dec

Figure 7. Monthly estimated daily global solar radiation for the 4 remained cities.

Table 6. Comparison of the regression a and b coefficients.

\begin{tabular}{|c|c|c|c|c|c|c|c|c|c|}
\hline & \multicolumn{3}{|c|}{ Country Model } & \multicolumn{3}{|c|}{$\begin{array}{l}\text { Turton's model } \\
a=0.30 b=0.40\end{array}$} & \multicolumn{3}{|c|}{$\begin{array}{c}\text { Rietveld's model } \\
\mathrm{a}=0.18 \mathrm{~b}=0.62\end{array}$} \\
\hline & $\begin{array}{c}\mathrm{MBE} \\
(\%)\end{array}$ & $\begin{array}{c}\text { RMSE } \\
(\%)\end{array}$ & $\mathrm{r}$ & $\begin{array}{c}\mathrm{MBE} \\
(\%)\end{array}$ & $\begin{array}{c}\text { RMSE } \\
(\%)\end{array}$ & $\mathrm{r}$ & $\begin{array}{c}\mathrm{MBE} \\
(\%)\end{array}$ & $\begin{array}{c}\text { RMSE } \\
(\%)\end{array}$ & $\mathrm{r}$ \\
\hline \multirow{2}{*}{ Region 1} & \multicolumn{3}{|c|}{$\mathrm{a}=-0.05 \mathrm{~b}=0.94$} & & & & & & \\
\hline & -3.27 & 4.71 & 0.98 & 41.64 & 45.93 & 0.89 & 30.97 & 33.25 & 0.86 \\
\hline \multirow{2}{*}{ Region 2} & \multicolumn{3}{|c|}{$\mathrm{a}=-0.02 \mathrm{~b}=0.74$} & & & & & & \\
\hline & 0.22 & 2.77 & 0.95 & 0.21 & 2.80 & 0.36 & 32.30 & 33.06 & 0.99 \\
\hline \multirow{2}{*}{ Region 3} & \multicolumn{3}{|c|}{$\mathrm{a}=0.14 \mathrm{~b}=1.13$} & & & & & & \\
\hline & 0.56 & 5.56 & 0.96 & -6.52 & 14.31 & 0.95 & -4.32 & 19.41 & 0.99 \\
\hline
\end{tabular}

Table 7. Some published Angstrom constants and those computed in this work.

\begin{tabular}{ccccc}
\hline \multirow{2}{*}{ Location } & $\begin{array}{c}\text { Angstrom } \\
\text { Constants }\end{array}$ & $\begin{array}{c}\text { Correlation } \\
\text { Coefficients }\end{array}$ & Source \\
\cline { 2 - 4 } & $\mathbf{a}$ & $\mathbf{b}$ & $\mathbf{r}$ & \\
\hline World & 0.23 & 0.48 & Black, et al. (1954) \\
Virginie (USA) & 0.25 & 0.5 & Glover, et al. (1958) \\
South East England (Europe) & 0.18 & 0.54 & Penman (1948) \\
Brisbane (Australia) & $0.23-0.35$ & $0.38-0.54$ & Penman (1948) \\
Wagneningen (Netherlands) & 0.20 & 0.56 & Cartledge (1973) \\
West-Africa & $-0.12-0.26$ & $0.99-9.50$ & Spitters (198) \\
Calabar (Nigeria) & 0.018 & 1.139 & Davies (1966) \\
Iseyia (Nigeria) & 0.20 & 0.75 & Augustine C. (2009) \\
Cameroon & $-0.04--0.14$ & $0.74-1.13$ & Falayi, et al. (2008) \\
Douala (Cameroon) & -0.04 & 0.98 & Mbiaké, et al. (2017) \\
Ngaoundéré (Cameroon) & -0.02 & 0.74 & Mbiaké, et al. (2017) \\
Maroua (Cameroon) & -0.15 & $1.13^{2}$ & Mbiaké, et al. (2017) \\
\hline
\end{tabular}

\section{Conclusions}

As others researchers who applied the Angstrom type regression model for estimating global solar radiation, we used this model to obtain, for the first time, the 
Table 8. The estimated values of the solar radiation the unknown solar cities radiation.

\begin{tabular}{|c|c|c|c|c|c|c|c|c|c|c|c|}
\hline \multirow[t]{2}{*}{ Month } & \multicolumn{2}{|c|}{ Common values } & \multicolumn{4}{|c|}{ Sunshine duration } & \multicolumn{4}{|c|}{ Estimated solar radiation: $\mathrm{H}_{\text {est }}$} & \multirow{2}{*}{$\begin{array}{c}\text { Region 1 } \\
H_{Y D N}\end{array}$} \\
\hline & $d_{0}$ & $H_{0}$ & Manfé & Dschang & Yoko & Koundja & Manfé & Dschang & Yoko & Koundja & \\
\hline January & 11.72 & 9.48 & 5.58 & 6.91 & 8.03 & 8.35 & 3.37 & 4.78 & 5.63 & 5.87 & 4.27 \\
\hline February & 11.83 & 10.01 & 5.57 & 6.14 & 8.04 & 8.38 & 3.93 & 4.38 & 5.89 & 6.16 & 4.71 \\
\hline March & 11.97 & 10.44 & 5.19 & 4.64 & 6.56 & 6.75 & 3.73 & 3.28 & 4.86 & 5.01 & 3.97 \\
\hline April & 12.13 & 10.44 & 5.50 & 4.74 & 6.60 & 7.23 & 3.93 & 3.30 & 4.82 & 5.33 & 4.13 \\
\hline May & 12.25 & 10.12 & 4.92 & 4.77 & 6.70 & 6.65 & 3.31 & 3.20 & 4.70 & 4.66 & 3.77 \\
\hline June & 12.32 & 9.87 & 4.13 & 3.59 & 5.80 & 6.49 & 2.62 & 2.21 & 3.88 & 4.40 & 2.89 \\
\hline July & 12.28 & 9.94 & 2.98 & 2.46 & 4.11 & 4.81 & 1.77 & 1.28 & 2.63 & 3.17 & 2.04 \\
\hline August & 12.17 & 10.22 & 1.92 & 2.50 & 3.80 & 4.41 & 1.01 & 1.46 & 2.49 & 2.97 & 1.76 \\
\hline September & 12.02 & 10.33 & 3.28 & 2.75 & 4.79 & 4.82 & 2.13 & 1.71 & 3.35 & 3.38 & 2.56 \\
\hline October & 11.87 & 10.34 & 4.23 & 3.79 & 5.93 & 6.14 & 2.86 & 2.51 & 4.21 & 4.38 & 2.90 \\
\hline November & 11.75 & 9.53 & 5.53 & 6.29 & 7.59 & 8.36 & 3.74 & 4.22 & 5.31 & 5.90 & 4.11 \\
\hline December & 11.69 & 9.26 & 5.90 & 6.55 & 7.82 & 8.06 & 3.93 & 4.41 & 5.36 & 5.54 & 4.23 \\
\hline
\end{tabular}

local values of $a$ and $b$ for Cameroon three regions that will lead a better prediction of the solar potential energy at a given site.

It can be point out that $a, b$ coefficient of the region 1,2 and 3 on Table 6 let the estimated values of global solar radiation close to the measured one. Moreover, this study shows that countries without enough in-situ meteorological equipment's to broadcast solar data can easily use Angstrom model to accurate the value of the predicted global solar radiation.

The better the predicted global solar are, the better evaluated potential energy for good exploitation will be.

\section{References}

[1] Lof, G.O.G., Duffie, J.A. and Smith, C.O. (1966) World Distribution of Solar Radiation. Solar Energy, 10, 27-37. https://doi.org/10.1016/0038-092X(66)90069-7

[2] Gueymard, C.A. and Thevenard, D. (2009) Monthly Average Clear-Sky Broadband Irradiance Database for Worldwide Solar Heat Gain and Building Cooling Load Calculations. Solar Energy, 83, 1998-2018.

[3] Rietveld, M.R. (1978) A New Method for Estimating the Regression Coefficient in the Formula Relating Solar Radiation to Sunshine. Agricultural Meteorology, 19, 243-252. https://doi.org/10.1016/0002-1571(78)90014-6

[4] Hutchinson, M.F., Booth, T.H., McMahon, J.P. and Nix, H.A. (1984) Estimating Monthly Mean Value of Daily Total Solar Radiation for Australia. Solar Energy, 32, 277-290. https://doi.org/10.1016/S0038-092X(84)80045-6

[5] Haluoani, N., Nguyen, C.T. and Vo-Ngoc, D. (1993) Calculation of Monthly Average Global Solar Radiation, on Horizontal Surfaces Using Daily Hours of Bright Sunshine. Solar Energy, 50, 247-258. https://doi.org/10.1016/0038-092X(93)90018-J

[6] Orozco, E.B. (1987) Gautemalan Solar Map. Solar and Wind Technology, 4, 381-388. https://doi.org/10.1016/0741-983X(87)90068-3

[7] Hawas, M.M. and Muner, T. (1983) Correlation between Global Radiation and 
Sunshine Data for India. Solar Energy, 30, 289-290.

https://doi.org/10.1016/0038-092X(83)90158-5

[8] Samuel, T.D.M.A. (1991) Estimation of Global Radiation for Sri-Lanka. Solar Energy, 47, 333-337. https://doi.org/10.1016/0038-092X(91)90026-S

[9] Raja, I.A. and Twidell, J.W. (1989) Distribution of Global Insolation over Pakistan. Solar Energy, 43, 355-357. https://doi.org/10.1016/0038-092X(89)90106-0

[10] Augustine, C. and Nnabuchi, M.N. (2009) Relationship between Global Solar Relation Sunshine Hours for Calabar, Port Harcourt and Enugu, Nigeria. International Journal of Physic Sciences, 4, 182-188.

[11] Khogali, A. (1983) Solar Radiation over Sudan-Comparison of Measured and Predicted Data. Solar Energy, 31, 45-53. https://doi.org/10.1016/0038-092X(83)90032-4

[12] Leung, C.T. (1980) The Fluctuation of Solar Irradiance in Hong Kong. Solar Energy, 25, 485-494. https://doi.org/10.1016/0038-092X(80)90080-8

[13] Rasmussen, M.S. (1998) Developing Simple, Operational, Consistent NDVI-Vegetation Models by Applying Environmental and Climatic Information: Part I. Assessment of Net Primary Production. International Journal of Remote Sensing, 19, 97-117. https://doi.org/10.1080/014311698216459

[14] Duffie, J.A. and Beckman, W.A. (1994) Solar Engineering of Thermal Processes. 2nd Edition, John Wiley \& Son, New York.

[15] Angström, A. (1924) Solar Terrestrial Radiation. Quarterly Journal of the Royal Meteorological Society, 50, 121-125.

[16] Precott, J.A. (1940) Evaporation from a Water Surface in Relation to Solar Radiation. Transactions of the Royal Society of South Australia, 64, 114-125.

[17] Trewartha, G.T. (1961) The Earth's Problem Climates. The University of Wisconsin, Madison.

[18] Turton, S.M. (1987) The Relationship between Total Irradiation and Sunshine Duration in the Humid Tropics. Solar Energy, 38, 353-354. https://doi.org/10.1016/0038-092X(87)90007-7

[19] Driesse, A. and Thevenard, D. (2002) A Test of Suebrcke's Sunshine-Radiation Relationship Using a Global Data Set. Solar Energy, 72, 167-175.

[20] Iqbal, M. (1983) An Introduction to Solar Radiation. Academic Press, Toronto.

[21] Baumgartner, T. (1979) Die Schwellenintensitat des Sonnenscheinautog-Raphen Campbell-Stokes an wolkenlosen Tagen, Arbeitsberichte der Schweizerischen Meteorologischen Zentralanstalt. Zürich.

[22] Painter, H.E. (1981) The Performance of a Campbell-Stokes Sunshine Recorder Compared with a Simultaneous Record of Normal Incidence Irradiance. Meteorological Magazine, 110, 102-109.

[23] Suehrcke, H., Bowden. R.S. and Hollnds, K.G.T. (2013) Relationship between sunshine Duration and Solar Radiation. Solar Energy, 92, 160-171. https://doi.org/10.1016/j.solener.2013.02.026

[24] Dunne, T. and Leopold L.B. (1978) Water in Environmental Planning. W.H. Freeman and Company, New York, 818.

[25] Kowal, J.M. and Kassam, A.H. (1978) Agricultural Ecology of Savanna: A Study of West Africa. Clarendon Press, Oxford, 403.

[26] Guyot, G. (1998) Physics of the Environment and Climate. John Wiley \& Son, Chichester, 632.

[27] Falayi, E.O., Adepitan, J.O. and Rabiu, A.B. (2008) Empirical Models for Correla- 
tion of Global Solar Radiation with Meteorological Data for Iseyin, Nigeria. International Journal of Physical Sciences, 3, 210-216.

[28] Davies, J.A. (1966) The Assessment of Evapotranspiration for Nigeria. Geografiska Annaler. Series A, Physical Geography, 48, 136-156.

https://doi.org/10.1080/04353676.1966.11879735 